Community: volume 6, nomor 1, April 2020

p-ISSN: 2477-5746 e-ISSN: 2502-0544

\title{
TRANSFORMASI BUDAYA MESEURAYA \\ PASCA PENANGGULANGAN BENCANA TSUNAMI 2004 DI GAMPONG KEUB KABUPATEN ACEH BARAT
}

\author{
Triyanto $^{1}$, Nellis Mardhiah ${ }^{2}$ \\ Prodi Sosiologi Universitas Teuku Umar ${ }^{1}$ \\ Prodi Administrasi Negara Universitas Teuku Umar ${ }^{2}$ \\ Email: Triyanto@utu.ac.id ${ }^{1}$, nellismardhiah@utu.ac.id ${ }^{2}$
}

\begin{abstract}
Indonesia as a country that is considered to have a wealth of disasters requires everyone to understand the potential for disasters in their respective regions. Not just understanding but also knowing how to deal with and even tame. The tsunami in Aceh which shocked the world forced international institutions to play an active role in disaster management. But mistakes in disaster management can have fatal consequences because in general disaster management is also accompanied by the restoration of social and cultural values there is a shift in social values in society. In this article, it is revealed how the Keub Gampoeng community performs the survey and reveals how disaster management can cause changes in the values of society. The study was conducted qualitatively with in-depth interviews and observation data collection techniques. The results showed that the community since before the tsunami had been accustomed to doing meseuraya, namely cleaning the surrounding environment, mosques, and also the community as individuals, especially those who were carrying out khanduri or carrying out celebrations such as marriage, circumcision, or showering (birth procession). Meanwhile, the handling of natural disasters by several nongovernment organizations (NGOs) can also result in changes in attitudes towards business activities. Especially handling disasters that are considered inappropriate. It can be exemplified is the implementation of a cash for a work program that is echoed as cooperation paid. The research data shows that the community is eventually accustomed to doing the payment for payment so that when village officials conduct the meeting without payment, the community is no longer eager to implement the meeting. Based on the above, the researcher recommends that anyone, both individuals and organizations, do not translate cash for work as paid mutual assistance. Cooperation must continue to get its meaning as working together for the common good. Thus, cooperation can still survive as a noble value inherent in the community members.
\end{abstract}

Keywords: Change, Meseuraya, NGO, Mutual Cooperation, Cash for Work. 
Community: volume 6, nomor 1, April 2020

p-ISSN: 2477-5746 e-ISSN: 2502-0544

\section{PENDAHULUAN}

Salah satu negara besar di Asia yang memiliki banyak potensi bencana adalah Indonesia. Berawal dari ujung barat, sebuah pulau besar bernama Sumatera bukan hanya tsunami sebagaimana terjadi di Aceh pada tahun 2004 dan Mentawai, namun juga berpotensi bencana berupa kebakaran hutan yang terjadi hampir di setiap tahun sepanjang musim kemarau. Bahkan dampaknya berupa kabut asap juga dirasakan sampai ke negeri tetangga yakni Malaysia dan Singapura. Bukan hanya tsunami dan kebakaran hutan saja tetapi masih ada gempa dan letusan gunung api juga membawa kerugian harta benda juga nyawa masyarakat Indonesia di wilayah ini.

Sepanjang Pulau Jawa juga memiliki potensi besar tentang bencana gempa bumi baik yang disebabkan pergerakan lempeng bumi maupun gempa yang disebabkan oleh karena aktivitas gunung berapi. Kebakaran hutan boleh dikatakan tidak terjadi, namun kebakaran rumah oleh karena konsleting listrik sering muncul di perkampungan masyarakat di kota-kota besar. Banjir juga sering terjadi pada saat musim penghujan yang dapat menyebabkan gagal panen, dan juga terputusnya akses transportasi.

Jika melihat data Badan Nasional Penanggulangan Bencana (BNPB), tentang potensi bencana di Indonesia bisa dikatakan wilayah negara ini penuh dengan potensi bencana. Secara geografis Indonesia terletak pada pertemuan empat lempeng tektonik, bukan hanya itu Indonesia juga disebut daerah sabuk vulkanik. Keberadaan Indonesia di wilayah empat lempeng tektonik mengakibatkan rawan akan bencana gempa bumi dan gelombang pasang seperti tsunami. Sementara posisinya di sabuk vulkanik berpotensi kuat terjadinya gempa tektonik atau letusan gunung api (BNPB Indonesia, 2013). Pada sisi yang lain Indonesia juga beriklim tropis yang terdapat dua musim yakni panas dan hujan, sehingga pada saat tertentu dapat mengakibatkan banjir, tanah longsor, kekeringan dan lain-lainnya.

Aceh yang berada di ujung Pulau Sumatera pada akhir tahun 2004, tepatnya tanggal 26 Desember di pagi hari telah terjadi tsunami dengan korban ratusan ribu jiwa, rumah, dan harta benda lainnya. Aceh telah luluh lantak rata dengan tanah, Kota Banda Aceh dan sepanjang pantai barat disapu ombak besar. Kota Banda Aceh, Lhok Nga, Kota Calang (Aceh Jaya), Kota Meulaboh (Aceh Barat) dan desa-desa sepanjang ratusan kilometer hancur diterjang gelombang tsunami.

Banyaknya korban jiwa dapat diprediksikan mengakibatkan hancurnya struktur sosial masyarakat sepanjang wilayah ini. Banyaknya korban harta benda juga mampu mengakibatkan terjadinya perubahan nilai-nilai yang terjadi pada masyarakat. Kebutuhan biologis atau kebutuhan akan dorongan naluri yang terabaikan mampu merusak konsensus individu sebagai warga dari sebuah masyarakat. Bukan hanya itu, penanganan korban yang salah juga mampu merusak sistem nilai yang telah lama terbentuk. 
Community: volume 6, nomor 1, April 2020

p-ISSN: 2477-5746 e-ISSN: 2502-0544

Sebuah desa di wilayah Kecamatan Arongan Lambalek yang disebut dengan Gampoeng Keub, merupakan desa yang jauh dari kota kabupaten (Meulaboh) juga merupakan sebuah desa yang menerima dampak besar terjangan tsunami tahun 2004. Masyarakat gampong ini telah menerima bantuan baik dari dari NGO berupa bangunan rumah dan juga biaya hidup sehari-hari (pada masa penanggulangan bencana). Bukan hanya itu tetapi masyarakat juga menjalankan program cash for work. Pertanyaan menarik adalah bagaimana masyarakat dalam melaksanakan meseuraya dan bagaimana pelaksanaan program cash for work yang mengakibatkan terjadinya perubahan nilainilai dan keberlangsungan meseuraya di Gampoeng Keub? Ini merupakan sebuah potret dari secuil penanggulangan bencana yang terjadi pada masyarakat.

\section{TINJAUAN PUSTAKA}

A. Meseuraya

Meseuraya adalah sebuah istilah Bahasa Aceh dimana secara teknis masyarakat melakukan kerja bersama dikoordinir oleh pemimpin gampoeng. Sejak dahulu kala masyarakat Aceh memiliki tradisi meseuraya, meskipun pada saat ini boleh dikatakan telah luntur. Tradisi meseuraya ini sering dilakukan masyarakat di pedesaan maupun di perkotaan. Namun masyarakat pedesaan lebih memiliki intensitas yang tinggi dibandingkan pelaksanaan di perkotaan. Lebih tepatnya meseuraya di perkotaan mengalami transformasi dari bekerjasama secara fisik dan sekarang lebih sering dilakukan dengan partisipasinya melalui penggalangan dana.

Sebuah contoh meseuraya yang jelas tampak pembangunan masjid Al-Muhajirin Cot Kandeh, sebuah dusun di wilayah Gampoeng Lapang dimana masyarakat mulai berkurang partisipasinya dalam bentuk kerja fisik, namun lebih berpartisipasi dalam pengumpulan dana untuk pembangunan. Pada tahun 2006 sampai dengan 2015, partisipasi masyarakat dalam pembangunan masjid lebih terfokus pada keterlibatan fisik. Ini dilakukan meseuraya seperti pembersihan area pembangunan dan melakukan pengecoran secara bersama-sama. Dana pembangunan sendiri diperoleh justeru banyak dari pihak luar meskipun dari warga masyarakat sendiri juga ada. Artinya pendanaan pembangunan difokuskan penggalangan dana yang dihimpun dari lembagalembaga/organisasi-organisasi tertentu baik pemerintah maupun non pemerintah dan partisipasi masyarakat yang bersedia secara sukarela.

Keterlibatan masyarakat itu makin lama semakin menurun, hingga suatu ketika dalam musyawarah ditawarkan sebuah bentuk partisipasi masyarakat yang dipandang lebih baik dalam proses pembangunan masjid tersebut. Sistem yang ditawarkan pemimpin dusun bersama pengurus Badan Kemakmuran Masjid dan para tokoh masyarakat, mampu menarik partisipasi masyarakat untuk bersama-sama membangun masjid dari sisi kepeduliannya terhadap pembangunan masjid. Sampai saat ini 
Community: volume 6, nomor 1, April 2020

p-ISSN: 2477-5746 e-ISSN: 2502-0544

partisipasi meseuraya dalam bentuk ini menampakkan eksistensi masyarakat. Masyarakat bukan saja merasa dianggap dan diperlakukan sebagai bagian warga tetapi juga merasa memiliki masjid yang bersama-sama dibangunnya.

Dengan sedikit paparan di atas akhirnya dapat dipahami bahwa yang dimaksudkan sebagai meseuraya adalah sebuah aktivitas kerja yang dilakukan oleh warga masyarakat secara bersama-sama demi mencapai tujuan bersama. Artinya dengan seperti ini dapat disamakan dengan definisi gotong royong menurut Bahasa Indonesia (Kemdikbud, 2012).

\section{B. Cash for Work Program}

Pasca tsunami di Aceh tahun 2004 banyak lembaga-lembaga baik pemerintah maupun non pemerintah (NGO) yang melakukan proses rehabilitasi dan rekonstruksi dalam penanggulangan bencana. Beberapa lembaga tersebut memiliki program berupa cash for work. Kegiatan ini sesungguhnya adalah pengerahan masyarakat dalam melakukan kerja khususnya pembersihan lingkungan dari sampah-sampah yang diakibatkan dari peristiwa tsunami.

Sebagaimana diketahui dampak tsunami salah satunya adalah banyaknya sampah yang berserakan baik di area persawahan atau di daerah-daerah tempat tinggal penduduk. Kondisi seperti ini memerlukan tenaga yang banyak untuk membersihkan kembali, namun tidak memerlukan skill yang tinggi untuk melakukannya. Untuk itu dikerahkan warga masyarakat untuk mengatasi masalah seperti itu, selain tenaga masyarakat juga diperlukan dana yang cukup. Dana untuk membayar masyarakat ini dapat dikucurkan dengan program cash for work (uang tunai untuk pekerjaan).

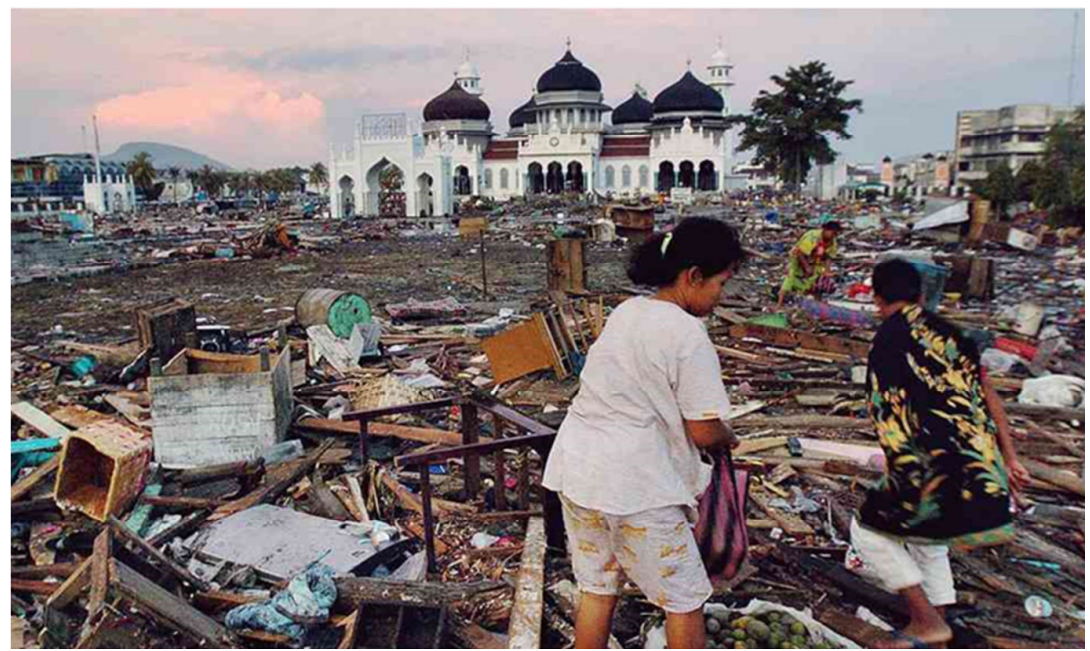

Sumber gambar: http://www.kompasiana.com

Gambar 1: Sampah-sampah berserakan akibat Tsunami di sekitar Masjid Baitur Rahman Banda Aceh 2004 (Kompasiana, 2015) 
Community: volume 6, nomor 1, April 2020

p-ISSN: 2477-5746 e-ISSN: 2502-0544

Pada tahun 2017 yang lalu, istilah cash for work muncul berkaitan dengan penggunaan dana desa yang digelontorkan kepada pemerintah desa. Presiden Republik Indonesia (Joko Widodo) mengatakan bahwa penggunaan dana desa harus dilakukan dengan model cash for work (Kuwado, 2017). Istilah ini kemudian menjadi sama dengan istilah lama yang pernah muncul pada saat orde baru yaitu padat karya. Padat karya dilakukan untuk membuka lapangan kerja untuk masyarakat sehingga kemiskinan bisa dientaskan dan kesejahteraan dapat ditingkatkan. Namun padat karya yang pernah dilakukan pada masa yang lalu hanya sesaat sehingga dampaknya tidak sanggup mengangkat masyarakat keluar dari kemiskinan.

Kini padat karya muncul kembali dengan diperkuat istilah asing yang pernah dilakukan NGO di Aceh pada masa rehabilitasi dan rekonstruksi Tsunami tahun 2004, yakni cash for work. Dukungan dana yang cukup besar juga bakal mewarnai pelaksanaan program ini. Sedikit berbeda, cash for work yang pernah ada di Aceh pasca Tsunami hanya fokus pada kerja membersihkan lingkungan oleh karena dampak tsunami, kini cash for work bukan sekedar kerja membersihkan lingkungan, namun lebih serius lagi karena memiliki tujuan mengentaskan kemiskinan, meningkatkan pelayanan publik, memajukan ekonomi desa, mengatasi kesenjangan desa dan kota, serta memperkuat desa sebagai subyek pembangunan (Indonesia, 2014).

\section{Transformasi Budaya}

Kata transformasi dalam kamus Bahasa Indonesia berarti perubahan rupa, namun penjelasannya lebih lanjut transformasi juga mengandung perubahan akan bentuk, sifat, fungsi, dan sebagainya (KBBI Online, 2012). Sementara itu transformasi menurut Rasyid Yunus lebih mengarah pada perpindahan dari suatu hal menuju arah yang lain yang bersifat baru yang mengalami perubahan (Yunus, 2013). Namun Rasyid lebih menekankan bahwa perubahan dimaksud tidak berkaitan dengan struktur yang ada. Pemahaman penulis inti dalam pernyataan Rasyid jika dihubungkan dengan budaya adalah terjadinya perubahan yang tidak meliputi struktur yang ada dalam budaya tersebut.

Lebih lanjut lagi penjelasan Rasyid mempertajam makna transformasi dimana istilah ini berhubungan dengan evolusi budaya. Menilik kata evolusi memiliki makna perubahan secara perlahan-lahan, bisa juga disebut sebagai perubahan setahap demi setahap. Pada kesimpulannya tentang transformasi, Rasyid menyebut perpindahan dari satu tempat ke tempat yang lainnya. Khususnya berkaitan dengan nilai-nilai budaya Huyula yang bermakna tolong menolong yang sudah menjadi sebuah sistem tersendiri.

Pranadji dan Hastuti memiliki terjemahan yang bisa dikatakan sama dengan Rasyid, namun memiliki referensi yang berbeda dimana menunjuk pada pandangan 
Community: volume 6, nomor 1, April 2020

p-ISSN: 2477-5746 e-ISSN: 2502-0544

Neufebet dan Guralnik. Referensi Pranadji dan Hastuti tersebut mengambil terjemahan Bahasa Inggris transformation dimana transform bermakna perubahan sedangkan transformation diterjemahkan sebagai proses perubahan. Lebih dalam lagi, sekaligus membedakan dengan Rasyid adalah bahwa Neufebet dan Guralnik yang dikutip Pranadji dan Hastuti mengindikasikan bahwa perubahan yang terjadi bukan hanya bentuk saja, tetapi juga ciri dan strukturnya (Tri Pranadji, 2004).

Konsep yang lebih lanjut lagi ditunjukkan oleh Enos (Rumansara, 2013) dimana transformasi bukan terletak pada proses perubahannya melainkan hasil dari proses perubahan itu sendiri. Dengan demikian antara transformasi dengan perubahan memiliki makna yang berbeda meskipun dapat disinonimkan. Konsep milik Rumansara bisa saja dimaknakan berbeda dengan yang lainnya, tentu hanya karena menitikberatkan pada hasil dan bukan pada prosesnya. Akan tetapi jika dimaknakan sama juga bisa, dengan tambahan memperjelas tentang perubahan dari sebelumnya ke arah yang baru.

\section{METODE PENELITIAN}

Penelitian ini dilakukan dengan pendekatan kualitatif, teknik pengumpulan data dengan interview dan observasi. Penentuan informan dilakukan secara purposive sampling, yaitu memilih orang-orang yang akan dijadikan informan berdasarkan pengetahuan atau pemahaman serta keahliannya tentang masalah yang diangkat dalam penelitian ini (Sugiyono, 2013). Sedangkan analisis data dilakukan dengan konsep Miles dan Huberman dimana melalui tiga tahapan yakni memilah dan memilih data yang sesuai dengan konteksnya, kemudian data-data tersebut di-display-kan dimana juga dilakukan kategorisasi data, dan terakhir dengan melakukan verifikasi data. Verifikasi data ini hasil akhirnya adalah kesimpulan yang diambil oleh peneliti.

\section{TEMUAN DAN PEMBAHASAN}

\section{Pelaksanaan Meseuraya}

Beberapa pertanyaan penelitian telah disampaikan kepada informan mengenai hal-hal yang berkaitan dengan meseuraya. Untuk melihat adanya transformasi budaya meseuraya penting untuk dikemukakan bagaimana sebelum dan pasca tsunami. Namun Provinsi Aceh yang merupakan wilayah konflik, kondisi sebelum tsunami tampaknya juga dipengaruhi situasi ini. Sebagai contoh perngakuan Geuchik (kepala desa) bagaimana mudahnya mengerahkan masyarakat untuk melakukan meseuraya.

"Pada masa itu sangat mudah, apalagi atas nama TNI/POLRI kita katakan saja bahwa pihak keamanan (TNI/POLRI) meminta untuk dibersihkan jalan dan parit-parit di wilayah gampong agar gampong bersih dan bebas penyakit, pasti semua warga akan keluar untuk melakukan meseuraya ini." 
Community: volume 6, nomor 1, April 2020

p-ISSN: 2477-5746 e-ISSN: 2502-0544

Pada sisi yang berbeda Anwar sebagai warga Keub lebih menekankan bahwa ada kepuasan tersendiri ketika dapat melakukan meseuraya:

"Dahulu kami sangat senang melakukan meseuraya itu, rasanya menyenangkan. Mungkin karena satu pekerjaan dilakukan bersama-sama, rasanya memang menjadi lebih ringan. Yang pasti semua senang karena dengan mengikuti meseuraya ini bisa berkumpul bersama, bercanda bersama dan setelah selesai rasanya senang saja."

Masa konflik memang membuat warga serba ketakutan, takut melakukan tindakan-tindakan salah yang mengakibatkan pihak pemerintah maupun yang sebelah menjadi halal untuk memukul atau menganiaya warga yang dianggap bersalah atau berat sebelah. Dengan demikian bila ada permintaan dari pihak-pihak berkonflik biasanya akan cepat direspon oleh warga. Keuchik sebagai leader masyarakat di gampoeng mengakui bahwa masa sebelum tsunami dimana situasi konflik meseuraya bisa dilakukan tiga kali dalam seminggu.

Ibrahim, Samsidar, Nafi juga mengisahkan bagaimana aktivitas meseuraya berjalan dengan baik dan penuh semangat pada masa lampau. Setiap waktu liburan sering dilakukan kegiatan meseuraya ini, bahkan dapat menjangkau sudut-sudut gampoeng atau tempat yang tidak ada warganya tinggal. Bukan hanya Ibrahim, Samsidar dan Nafi saja yang mencermati meseuraya ini, tetapi juga warga lainnya termasuk beberapa informan seperti Amir, Irwan, dan Ismail. Intinya menunjukkan kesamaan diantara semua warga masyarakat.

Tentu meseuraya merupakan hal menarik dilakukan pada jaman dahulu, apalagi sesungguhnya meseuraya yang sama artinya dengan gotong royong itu merupakan aktivitas naluriah manusia sehingga aktivitas seperti ini bisa mengalami perubahan atau bahkan nilai-nilainya menjadi hilang (Maulana, 2014).

Gotong royong (meseuraya), merupakan aktivitas yang dilakukan bersama-sama warga masyarakat, semua memiliki kewajiban untuk melakukan kegiatan ini. Karena manfaatnya dapat dirasakan bersama dan pada dasarnya juga untuk mencapai tujuan bersama. Orang-orang yang tidak mau melakukan aktivitas ini, akan disebut sebagai orang yang tidak peduli terhadap sesama warga bahkan secara ekstrim merupakan pengkhianat.

Hal menarik dalam meseuraya yang dilakukan jaman dahulu sebagaimana dikatakan Nafi adalah:

"Dahulu orang sangat suka sekali meseuraya, karena begitu orang sudah lelah setelah beberapa jam bekerja maka beristirahat. Pada saat itirahat itu datang warga yang lainnya yang mengantar minum dan makanan ringan seperti ubi (ketela dan singkong). Apalagi masa itu tidak semua orang sempat membeli ubi, sehingga ada ubi dan dimakan bersama-sama itulah yang memberikan kenikmatan untuk selalu melakukan meseuraya". 
Community: volume 6, nomor 1, April 2020

p-ISSN: 2477-5746 e-ISSN: 2502-0544

Tadjuddin memberikan gambaran bahwa gotong royong itu merupakan amal usaha dan karya bersama, bahkan jerih payah bersama. Gotong royong juga memiliki azas kesadaran, kerja rohaniah dan jasmaniah. Gotong royong juga merupakan perhiasan hidup dalam bermasyarakat. Oleh karenanya gotong royong adalah faham dinamis sehingga sewaktu-waktu dapat berubah (Effendi, 2013).

Jika Tadjuddin mengatakan bahwa gotong royong merupakan kerja rohaniah, dan Anwar sebagai masyarakat Keub memberikan pernyataannya senang karena meseuraya membuatnya menjadi berkumpul dan bercanda bersama, maka Koentjaraningrat memberikan literasi bahwa sesungguhnya setiap manusia memiliki dorongan naluri ingin berkumpul dan bertemu dengan sesamanya (Koentjaraningrat, 2009). Dengan keterlibatannya dalam kegiatan meseuraya, berarti terpenuhi salah satu dorongan nalurinya.

\section{Cash for Work dan Perubahan Nilai-Nilai Meseuraya}

Tsunami 2004 menjadi titik balik dan tolak ukuran terjadinya perubahan sikap dan aktivitas warga masyarakat dalam hal meseuraya ini. Seiring dengan rusaknya sarana prasarana yang ada pada masyarakat, tsunami seolah juga merusak nilai-nilai sosial yang berlaku. meseuraya yang diklaim mudah dilakukan sebelum tsunami, kini menjadi susah setelah masyarakat dan wilayahnya diterjang air bah tsunami.

Tiba-tiba semua warga merasa kesulitan untuk melakukan kerja bersama-sama lazimnya dilakukan masyarakat perdesaan. Warga mulai lebih mengutamakan kebutuhan dapurnya dari pada melakukan meseuraya yang dianjurkan oleh pemerintah gampoeng. Keuchik sebagai leader dan tokoh masyarakat seolah sudah tidak ada artinya dalam hal ini. Anwar (bukan nama sesungguhnya) mengisahkan bagaimana masyarakat tidak mau melakukan meseuraya lagi.

"Pasca tsunami agak susah meminta swadaya dari masyarakat, awal tsunami hal tersebut dianggap sebuah kewajaran karena melihat kondisi masyarakat hampir semuanya dalam kondisi memerlukan bantuan dari pihak lain, namun sayangnya perubahan kebiasaan masyarakat tersebut sukar untuk dirubah saat ini dikarenakan kebiasaan NGO yang selalu memberikan upah kepada setiap pekerjaan yang dilakukan oleh masyarakat baik kegiatan kepentingan umum maupun kegiatan untuk kepentingan pribadi dari masyarakat itu sendiri, sehingga gotong royong yang didasari dari sebuah kesadaran sangat sulit untuk diwujudkan."

Nafi (bukan nama sebenarnya) juga mengatakan perihal bantuan NGO yang dipandangnya ada kesalahan sehingga mengakibatkan hilangnya nilai-nilai meseuraya di gampoengnya:

"Setelah tsunami menghantam daerahnya, tidak lama NGO berdatangan dengan maksud membantu masyarakat. Dengan banyaknya bantuan NGO tersebut, mulai tampak terjadi perubahan baik itu berkaitan dengan perilaku masyarakat 
Community: volume 6, nomor 1, April 2020

p-ISSN: 2477-5746 e-ISSN: 2502-0544

yang mulai ketergantungan maupun semangat kebersamaan dan meseuraya mulai luntur. Perubahan perilaku ini disebabkan karena NGO telah dimanjakan para petani dengan pemberian modal, baik itu hibah maupun pinjaman lunak untuk mengolah lahannya, termasuk bibit dan pupuk dan sebagiannya juga dibantu oleh pemerintah."

Selain itu beberapa masyarakat juga menunjuk pada pelaksanaan program cash for work yang dilakukan. Pemerintah gampoeng mengerahkan masyarakat untuk melakukan pembersihan sisa-sisa tsunami di wilayahnya, namun pada masa seperti itu tidak mudah mengumpulkan masyarakat untuk bekerja. Bahkan dengan membawa nama TNI/Polri, masyarakat juga tetap susah untuk dikumpulkan. Ini kondisi yang sangat berbeda dengan saat-saat konflik. Para tokoh gampoeng pun sesungguhnya juga berhatihati untuk membawa nama TNI/Polri, karena situasinya warga masyarakat baru terkena tsunami sehingga kalau membawa-bawa nama TNI/Polri (walaupun diizinkan pihak TNI/Polri) yang sudah biasa dilakukan saat konflik pasti akan dianggap seolah-olah tidak paham perasaan warga.

Mengenai kemungkinan untuk dilakukan sistem denda bagi warga masyarakat yang tidak patuh untuk melakukan meseuraya, Pak Keuchik memberikan penjelasan sebagai berikut:

"Kita tidak bisa memberikan denda kepada masyarakat yang tidak mau meseuraya. Dahulu ketika dengan membawa nama TNI/Polri, masyarakat takut dan mau melakukan meseuraya ini. Namun setelah tsunami ini tidak bisa juga, lagi pula tidak tepat alasan itu, malah lebih masuk akal saat mereka beralasan tidak bisa mengikuti karena berhubungan dengan orang sekeluarga."

Beberapa masyarakat bisa memberlakukan denda bagi warga masyarakat yang tidak bisa mengikuti aktivitas meseuraya. Seperti yang diterapkan di Balun Kabupaten Lamongan, aparat desa memberikan denda kepada warga yang tidak mau melakukan gotong royong atau meseuraya. Hal ini dilakukan dalam rangka menjaga kelestarian gotong royong. Kajian Puput dan Sarmini ini menunjukkan bahwa masyarakat tidak memilih membayar denda, kecuali beberapa warga yang kebetulan juga tidak bisa mengelak dari kesibukannya sendiri (Puput Anggorowati, 2015).

Akhirnya, orang-orang yang diberikan tugas mengumpulkan warga mengambil jalan yang mudah, yaitu mengatakan gotong royong dan akan dibayar. Program cash for work tentunya sangat bagus, apalagi program ini digagas dan dilakukan oleh lembagalembaga NGO internasional. Namun level gampoeng, utamanya para leader yang ditunjuk untuk memobilisasi warga menterjemahkan sebagai meseuraya yang dibayar membawa dampak terhadap kerusakan nilai-nilai sosial khususnya meseuraya itu sendiri.

Amir, Irwan, dan Ismail menyatakan bahwa keinginan untuk melakukan meseuraya itu tetap ada dalam hati masyarakat, namun pada saat ini kebutuhan dapur 
lebih penting dibandingkan kerja bersama-sama warga lainnya hanya untuk bersihbersih gampoeng. Bukan hanya, setelah diperdalam ada kenyataan yang dirasa pahit oleh warga masyarakat, meskipun itu tidak benar secara fakta.

Banyak orang kecewa dengan meseuraya yang dilakukan pada waktu akhir-akhir kebetulan NGO sudah pergi, namun kebersihan masih diperlukan agar terjamin kesehatan warga. Warga dikerahkan untuk bersih-bersih, dan banyak warga yang datang. Kekecewaan terjadi tatkala pembersihan wilayah gampoeng selesai. Tidak ada upah dan tidak ada apapun kecuali lelah. Masyarakt pun bertanya-tanya siapa sesungguhnya yang bertugas untuk membagikan upahnya.

Pada saat cash for work yang didanai NGO, keuchik atau orang lainnya yang ditunjuk untuk memberikan upah kepada warga masyarakat yang bekerja membersihkan area kerja. Sehingga pada saat meseuraya tidak diberikan upah lagi masyarakat menganggap keuchik melakukan penyelewengan dana. Sangat beruntung hal ini tidak berimbas pada aksi kekerasan warga terhadap keuchik atau orang-orang yang biasa ditugaskan oleh NGO yang memberikan bantuan.

Aparat desa mampu memberikan penjelasan kepada warga sehingga masyarakat dapat memahami situasinya dan tidak menuntut upahnya saat meseuraya di akhir-akhir itu. Namun masyarakat sudah terlanjur terbiasa, yakni melakukan aktivitas meseuraya dengan dibayar, sehingga saat ini pun saat warga masyarakat dihimbau untuk meseuraya tetapi tidak upah, warga sudah enggan melakukan. Pikiran dan perasaan sudah terpola dengan bekerja dan menerima upah.

Seharusnya aktivitas meseuraya tidak perlu diberikan upah, karena meseuraya adalah kerja bersama demi tujuan bersama sebagai warga masyarakat. Masyarakat bergerak melakukan kegiatan meseuraya konteknya memberikan tenaganya untuk pembangunan atau membersihkan masjid, memperbaiki atau membersihkan jalan, membangun jembatan, sekolah dan lainnya yang intinya dilakukan bersama demi kebutuhan bersama, sehingga tidak diperlukan upah atau pembayaran (Diaswati Mardiasmo, 2013).

Apa yang terjadi di Gampoeng Keub menjadi perhatian penting, agar pelaksanaan penanggulangan bencana dilakukan dengan cermat. Tentu bukan hanya dana saja yang diperlukan, tetapi juga diperlukan tenaga ahli yang bukan hanya ahli dalam mendistribusikan barang bantuan tetapi juga ahli memahami masyarakat sehingga program-program yang dilaksanakan bisa dijaga jangan sampai menyentuh dan merusak nilai-nilai luhur yang ada dalam masyarakat.

Masyarakat Keub bukan tidak lagi mengenal meseuraya, namun membatasi diri. Pelaksanaan meseuraya tidak lagi dilakukan di tempat-tempat umum kecuali kepentingan agama (masjid). Dalam hal kepentingan agama masyarakat masih berbondong-bondong secara sukarela membangun dan membersihkan masjid, dan melancarkan kegiatan hari besar Islam. Sementara yang sifatnya pelaksanaan di tempat 
Community: volume 6, nomor 1, April 2020

p-ISSN: 2477-5746 e-ISSN: 2502-0544

khusus seperti warga masyarakat yang melaksanakan hajatan perkawinan, sunatan, melahirkan dan acara kematian warga, masyarakat juga masih menyempatkan dirinya untuk membantu dan melaksanakan meseuraya bersama-sama.

\section{PENUTUP}

Berdasarkan uraian di atas, maka dapat diambil simpulan mengenai bagaimana meseuraya dilakukan dan bagaimana cash for work mampu merubah nilai-nilai meseuraya.

1. Meseuraya dilakukan dengan baik sejak dahulu kala hingga saat tsunami 2004. Masyarakat melaksanakan dengan senang hati karena meseuraya adalah aktivitas bersama untuk mencapai tujuan bersama. Meseuraya juga merupakan ajang berkumpul bersama, berinteraksi dan bersosialisasi melampiaskan dorongan naluri yang telah terkandung dalam nurani setiap manusia. Selain itu, kondisi konflik yang terjadi saat itu turut mewarnai bagaimana mudahnya masyarakat diajak bersama-sama meseuraya membersihkan area gampoeng agar bersih dan sehat bagi warga.

2. Cash for Work merupakan program yang menarik yang diberikan NGO. Namun pelaksanaan di tingkat masyarakat yang menterjemahkan sebagai gotong royong dibayar menyebabkan terjadinya perubahan nilai budaya meseuraya ini. Pada awalnya cash for work sangat menyenangkan, karena mampu memberikan pendapatan bagi warga masyarakat yang terlibat apalagi masa pasca tsunami memang sangat sulit mendapatkan pekerjaan. Efeknya, ketika gotong royong tidak lagi dibayar, masyarakat mulai enggan untuk melakukannya. Berbeda keadaannya jika cash for work tidak dikatakan sebagai gotong royong yang dibayar, melainkan padat karya dimana diperlukan tenaga yang banyak untuk mengerjakan sesuatu dan semua tenaga akan dibayar sesuai yang sudah disepakati bersama atau ditetapkan pihak yang memberikan kerja. Banyak yang beralasan sedang bekerja untuk memperjuangkan agar dapurnya selalu ngepul. Alasannya sangat masuk akal dan logis, karena setiap orang tua bertanggungjawab pada keluarganya. Dimungkinkan, ini bukan satu-satunya penyebab terjadinya perubahan itu. Kedepan disarankan agar pelaksana program agar lebih bijaksana dalam menggunakan istilah yang sering digunakan masyarakat, sehingga tidak merubah makna dan persepsi masyarakat dalam menjalankan aktivitas seperti meseuraya ini.

\section{DAFTAR PUSTAKA}

BNPB Indonesia (2013) Definisi dan Jenis Bencana, BNPB Indonesia. Available at: https://bnpb.go.id//potensi-bencana (Accessed: 1 March 2019). 
Community: volume 6, nomor 1, April 2020

p-ISSN: 2477-5746 e-ISSN: 2502-0544

Diaswati Mardiasmo, P. B. (2013) 'Community Response to Disasters in Indonesia: Gotong Royong; a Double Edged-Sword', in Proceedings of the 9th Annual International Conference of the International Institute for Infrastructure Renewal and Reconstruction ISBN: 978-1-921897-73-3.

Effendi, T. N. (2013) 'Budaya Gotong-Royong Masyarakat dalam Perubahan Sosial Saat Ini', Jurnal Pemikiran Sosiologi, 2(1).

Indonesia, R. (2014) Undang-Undang Republik Indonesia nomor 6 Tahun 2014 Tentang Desa. jAKARTA.

KBBI Online (2012) Definisi Transformasi, Badan Pengembangan dan Pembinaan Bahasa (Pusat Bahasa). Available at: https://kbbi.web.id/transformasi (Accessed: 10 March 2019).

Kemdikbud, B. P. dan P. B. (2012) Definisi Gotong Royong, KBBI Daring. Available at: https://kbbi.web.id/gotong royong (Accessed: 10 March 2019).

Koentjaraningrat (2009) Pengantar Ilmu Antropologi. Jakarta: Rineka Cipta.

Kompasiana, C. (2015) Pasca 10 Tahun Tsunami Aceh ke mana Perginya Puing Reruntuhan Sisa Tsunami, https://www.kompasiana.com/. Available at: https://www.kompasiana.com/yayasanaksicepattanggap/55e507344123bd31359 691e3/pasca-10-tahun-tsunami-aceh-kemana-perginya-puing-reruntuhan-sisatsunami (Accessed: 10 March 2019).

Kuwado, F. J. (2017) Jokowi Instruksikan Dana Desa Dikucurkan dengan Model 'Cash for Work', Tribunnews.com. Available at: https://www.tribunnews.com /nasional/2017/11/03/jokowi-instruksikan-dana-desa-dikucurkan-dengan-modelcash-for-work (Accessed: 10 March 2019).

Maulana, I. (2014) 'Metamorfosis Gotong Royong Dalam Pandangan Konstruksi Sosial', in Prosiding Penelitian \& Pengabdian Masyarakat (Prosiding KS: Riset \& PKM, Vol. 2 Nomor 1, ISSN: 2442-4480).

Puput Anggorowati, S. (2015) 'Pelaksanaan Gotong Royong di Era Global (Studi Kasus di Desa Balun Kecamatan Turi Kabupaten Lamongan)', Jurnal Kajian Moral dan Kewarganegaraan, 1(2).

Rumansara, E. H. (2013) 'Transformasi Upacara Adat Papua: Wor Dalam Lingkaran Hidup Orang Biak', Jurnal Humaniora, 15(2).

Sugiyono (2013) Metode Penelitian Kuantitatif Kualitatif Dan $R$ \& D. Bandung: Alfabeta.

Tri Pranadji, E. L. H. (2004) 'Transformasi Sosio-Budaya Dalam Pembangunan 
Community: volume 6, nomor 1, April 2020

p-ISSN: 2477-5746 e-ISSN: 2502-0544

Pedesaan', Analis Kebijakan Pertanian (AKP), 2(1). doi: http://dx.doi.org/ 10.21082/akp.v2n1.2004.77-92.

Yunus, R. (2013) 'Transformasi Nilai-Nilai Kebudayaan Lokal Sebagai Upaya Pembangunan Karakter Bangsa', Jurnal Pendidikan dan Penelitian (JPP), 14(1), pp. 65-77. Available at: https://ejournal.upi.edu/index.php/JER/article/ view/3508. 